Turning Point in Ethnic Succession." Civil rights legislation and job-training programs helped African-American women leave domestic service in the 1960 s. A booming economy and equal opportunity initiatives enabled many African-American women, like pre-World War I and post-1965 immigrants, to move into more desirable service and public-sector jobs.

\title{
Links on the Chain: Labor at Century's End
}

\author{
Leslie Ann Schuster and Robert L. Cvornyek \\ Rhode Island College
}

In October Rhode Island College sponsored a month-long general education series that considered labor's historic past, examined its current position, and helped project its future course. "Links on the Chain: Labor at Century's End" encompassed a variety of events with broad appeal in the academic and labor communities. The series coordinated several diverse programs including an exhibition of labor photography; films on the life of the worker; and panel discussions on the future of enterprise compacts, European and Latin American labor movements, community organizing, and occupational safety and health. Moreover, the program featured two regional conferences. The University and College Labor Education Association (UCLEA) held its Eastern Regional conference during the month as did the New England Historical Association (NEHA). This wellattended series brought labor leaders, community organizers, members of the Providence community, academics, and students together to discuss various issues facing workers and organizers.

The series opened with photographer Earl Dotter's exhibition "Images as History: A Worker's Life in Mine and Mill." Dotter's exhibit focused on living and working conditions in southern coal and mill towns but also reflected his current interest in child labor and occupational safety and health, especially among health-care workers. Dotter's incisive photographs underscored his lifelong commitment to "highlight individuals doing their best to improve their lot with self-respect and dignity."

The UCLEA conference hosted a series of workshops on the theme "In Diversity Strength." The keynote speaker, historian Jacqueline Jones, provided the historical context of organized labor's troubled past on race relations but highlighted its accomplishments and indicated that the union movement remains the single best hope for workplace equality. She pointed to employer manipulation, institutional segregation, and the media's equation of class with race as critical factors in perpetuating hostility and prejudice among American workers. 
Labor economist Barry Bluestone spoke on behalf of enterprise compacts, a new model of labor-management relations that would rebuild unions and improve the productive capacity of American industry. Bluestone demonstrated that the low wages, lost benefits, and high unemployment afflicting American workers today stem from a decline in industrial profits since 1973. Once American industry can match the quality and productivity of its foreign competitors, workers' standard of living will again begin to rise. To this end, Bluestone argued for replacing traditional adversarial relations between management and labor with enterprise compacts based on cooperation and teamwork. Quality and output will improve as workers and management share in production decisions, an option which has eluded labor as a result of broadly drawn management rights clauses. Commentator Paul Buhle maintained that labor's traditional conservatism would impede this innovative approach while John McDermott expressed concern that this model of labor relations left out unemployed and unorganized workers.

NEHA met at the college in mid-October and featured a panel on "Labor and Radicalism in 19th Century America." Timothy Fulop showed that principles of "gospel liberty" in the early republic informed the work of preacher Elias Smith to restrict privilege; democratize religion, government, and medicine; and uphold the "rights and abilities" of common people. Robert Weir argued that the radical social gospel movement of the Gilded Age remained limited in impact and neither transformed religious ideology nor improved "public perceptions of the labor movement." Scott Molloy examined the 1902 Pawtucket streetcar strike in which strikers did not censure older employees who chose to scab. Strikers recognized that participation by this group would be a "high-stakes gamble" and instead turned their anger on replacement workers. Molloy also maintained that because the streetcar company had become a metaphor for state corruption, the strike earned support from the middle class.

George Ross and Laurence Marlow addressed "European Labor at Century's End." Ross first documented the growing weakness of European labor as measured by declining union membership, loss of manufacturing jobs, and reduced political power-seen in labor's inability to protect the welfare state or social-democratic policies. He argued that the source of labor's decline lay with economic globalization and the turn from national political economies. With globalization, political elites have directed their energies toward international markets and undercut domestic employment. Industries have restructured for flexibility and "lean production" and now use the planet rather than the nation as their labor market. Ross declared that labor must develop strategies to organize the new work force and to meet management's shop-floor concerns while still protecting its members, and finally, that labor's new strategy must be international.

Marlow reviewed the British Labour party's diminishing commitment to social democracy. He argued that a critical moment came under Wilson 
in the 1960 s when the party took on the image of modernization and moved to discipline and stabilize the union movement. After a decade of fractious ideological conflict, it continued its moderate transformation in the 1980s under Kinnock, even abandoning the term "market socialism" for "supplyside socialism." Marlow pointed to the recent Labour party platform to illustrate that consumer issues and stabilization of the two-party system have replaced Labour's commitment to jobs and welfare policies. These issues were conspicuously absent from the platform, which presented Labour as a high-tech party committed to the protection of industry. Labour now focuses on acquiring the swing vote rather than social-democratic policies and protection of workers and unions.

The subject of community organizing and minority workers received careful consideration by a panel featuring Ashaki Binta, director of organizing, Black workers for Justice (BWJ) of Rocky Mount, North Carolina. Established in 1981 by black women employed at K-Mart, BWJ has developed in response to the absence of unions in the South to protect the working poor. Binta demonstrated that tactics of business unions are ineffective in the South, particularly in light of worsening economic conditions, and argued for innovative strategies to confront issues of social justice for communities and for workers. Binta offered several models currently used by $\mathrm{BWJ}$ to ensure workers' rights, including organizing outside the traditional union framework and forging close links between labor and the community. She focused on organizing in Hamlet, where a poultry processing plant fire killed 25 workers. Here BWJ undertook a year-long campaign to overcome the separation of community and workplace and break the political power of local antilabor politicians. 